\title{
Mitral cell responses to the odors of reward and nonreward
}

\author{
J. W. VOORHEES and N. R. REMLEY \\ Texas Christian University, Fort Worth, Texas 76129
}

\begin{abstract}
The purpose of this investigation was to determine if there were specific odor components in the goalbox of a straight alleyway following reward and nonreward trials. Behavioral research has convincingly demonstrated that, unless the goalbox is cleaned between animals, a pattern of slow running on nonreward trials and fast running on reward trials soon develops. It has been proposed that the rat emits an odor in the goalbox following nonreward which allows following conspecifics to predict the upcoming goal event before reaching the goalbox. Behavioral research has been unable to determine if there are specific odors associated with reward and nonreward, or if there is only one odor of varying concentration, or if only one odor is present and the cue for the other condition is merely the absence of that odor. The results of this study strongly suggest that there are specific odors in the goalbox as a result of nonreward and reward. They further suggest that these "reward" and "nonreward" odors are different from the odors of food and urine, and that the "reward" and "nonreward" odors, although different, may possibly be similar in chemical structure.
\end{abstract}

It has been reliably demonstrated that rats can discriminate reward vs. nonreward conditions in a straight alley as a function of the behavior of the animals that precede them in the apparatus (Howard \& McHose, 1974; Ludvigson \& Sytsma, 1967; Mellgren, Fouts, \& Martin, 1973; Pratt \& Ludvigson, 1970). Ludvigson and Sytsma (1967) proposed that a rat could leave odor cues in an alleyway that would forecast the upcoming goal event for any conspecifics that followed. In the Ludvigson and Sytsma study, all animals received the same condition on a given trial, and the squad of animals received the first trial before any received the second. When the goalbox was cleaned only between trials, allowing any apparent odor cues to accumulate on a single trial, a pattern of behavior of fast running on reward trials and slow running on nonreward trials emerged. When the goalbox was cleaned between animals, the pattern disappeared. Additional evidence that this pattern of running fast on reward trials and slowly on nonreward trials is mediated by odor discrimination on the part of the subjects was provided by Seago, Ludvigson, and Remley (1970). These investigations reported that olfactory bulbectomized rats failed to show the characteristic patterning when only apparent odor cues were relevant to the reward condition. When a light cue was added on reward trials, the anosmic animals were able to discriminate and showed the characteristic patterning.

This research was supported in part by the Texas Christian University Research Foundation. Reprint requests should be sent to N. R. Remley, Department of Psychology, Texas Christian University, Fort Worth, Texas 76129.
Ludvigson and others have postulated that this characteristic behavior pattern is determined by the discrimination of an odor associated with nonreward trials and covaries with an emotional response of frustration resulting from the absence of reward in an expected reward condition (Collerain \& Ludvigson, 1977; Howard \& McHose, 1974; Pratt \& Ludvigson, 1970; Wasserman \& Jensen, 1969). Collerain and Ludvigson (1972) also found that this "nonreward" odor was avoided or escaped from by animals in a T-maze. Also, the speed of exiting a chamber containing the odor emitted by a nonrewarded rat was faster than the approach speed (Mellgren, Fouts, \& Martin, 1973). The "nonreward" odor also resulted in subjects behaving as they might in a fear-producing situation (Cattarelli, Vernet-Maury, \& Chanel, 1974).

The "nonreward" odor concept has been investigated using many different approaches: changing the deprivation states of rats used as odor donors (Davis, Prytula, Noble, \& Mollenhour, 1976), mixing the sex of odor donors and test subjects (Eslinger \& Ludvigson, 1980), and double vs. single or random alteration (Prytula, Note 1). Even with all the work involving the manipulations of various environmental conditions in the alleyway, very little effort has been directed toward the physiological mechanisms of gencration or reception of these odors. Attempts to chemically isolate the odor of "nonreward" also have not been too successful (Eslinger, 1980).

Cattarelli, Vernet-Maury, Chanel, MacLeod, and Brandon (1975) recorded single-cell responses from the mitral cells of rat olfactory bulb during stimulation with various animal odors. They also used as stimuli "stress" odor from a shocked rat and odor 
taken from a T-maze where a rat had experienced reward (water) or nonreward. They reported a difference in percentage of inhibitory and excitatory responding cells to "reward" and "nonreward" odors. Their study did not offer any behavioral evidence that there was any specific odor in the T-maze, nor did they mention any specific control for the odor of water in the goalbox in the reward condition. Also, they did not report any data concerning any differential responses in individual cells to the different stimuli.

The present study represents an attempt to measure the responses of single mitral cells in the rat olfactory bulb to odors collected from an alleyway in which rats have experienced reward or nonreward. Odors of urine and food were also used as stimuli. Our purpose was to discover whether or not the rat's olfactory system was responsive to the odor of "nonreward," and to gather data that might allow us to describe any differences or similarities of this type of odor and any other odors that might be present in the goalbox.

\section{METHOD}

\section{Subjects}

The subjects used for the recording sessions were 28 female, albino, Sprague-Dawley rats, 90 days old at the onset of the recording phase. The subjects used for the generation of odor samples were 8 female, albino, Sprague-Dawley rats. All animals were individually housed and maintained on a 12-h light/dark cycle. Recording subjects had food and water available at all times except for $48 \mathrm{~h}$ prior to the recording session. At that time a daily ration of $12-13 \mathrm{~g}$ was made available. The odor-donor subjects had water available at all times, and food was provided to maintain them at $85 \%$ of free-feeding body weight.

\section{Apparatus}

The recording equipment was a modular system manufactured by Frederick Haer \& Co. Tungsten steel microelectrodes with a tip diameter of less than $1 \mu$ and impedance values of 5-15 MQ were used to record the single unit responses. Enhanced spike potentials were discriminated by passing the signal through a window discriminator. The output of the window discriminator was passed through a rate/interval analyzer. The output of the rate/interval analyzer was recorded as an integrated analog signal on a Bausch \& Lomb VOM-5 recording voltmeter. To allow for location of the mitral cell layer and visual monitoring of the recording, the raw signal was displayed on one beam of a dual-beam oscilloscope. The other beam of the oscilloscope was used to display the multiplexed output of the window discriminator for visual adjustment of the window width. Throughout the course of the recording session, heart rate was monitored on a second oscilloscope. Body temperature of the subjects was maintained within a range of $36^{\circ}-38^{\circ} \mathrm{C}$ with a circulating water heating pad and monitored by means of a rectal probe. Respiration was provided by a Harvard Small Animal Respirator, adjusted so as to exchange a volume of $10 \mathrm{cc}$ of air at a rate of $110 \mathrm{vol} / \mathrm{min}$.

Olfactory stimulation was provided by a carrier air supply to which were added odors from: (1) papers taken from the runway goalbox after two nonreward trials, (2) papers taken from the runway goalbox after two reward trials, (3) a runway length section of paper to which urine from a donor rat had been added, and (4) a runway length section of paper to which a few pellets of food from the goalbox food cup were added. The latter two paper

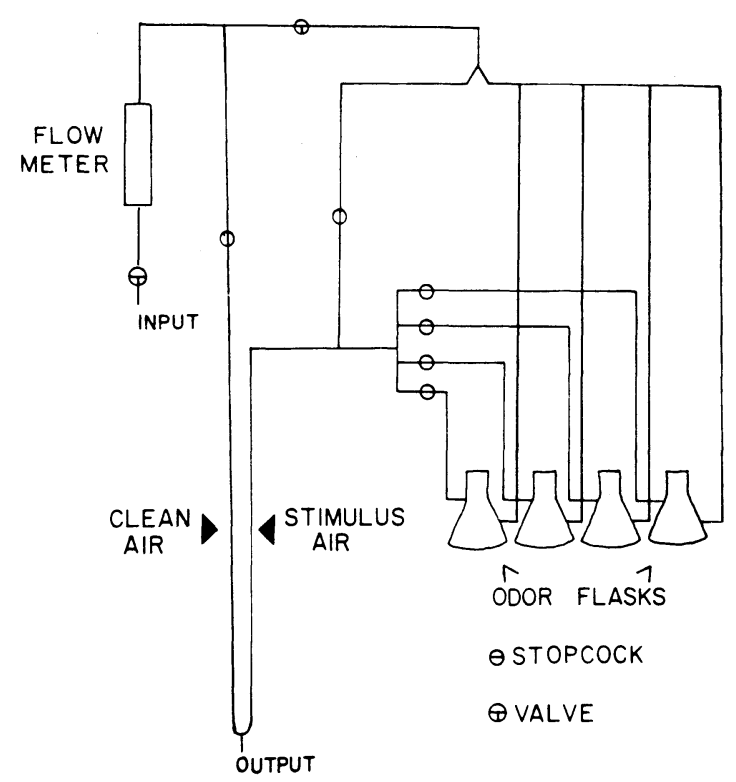

Figure 1. The odor stimulus delivery system. The input was dried, filtered, and rehydrated air.

samples were taken from the same roll of paper that lined the runway but had not been in contact with any of the subjects.

The carrier air sample was dried by a Dririte filter and then purified by being passed through activated charcoal. It was then rehydrated by being passed through distilled water prior to entering the stimulus delivery system.

The stimulus delivery system allowed for a monitored flow rate of $150 \mathrm{ml} / \mathrm{min}$. After the carrier stream left the flow meter, it passed through two separate lines, the clean-air line and the stimulus-air line. The stimulus-air line further divided at a manifold into four separate lines which entered glass-stoppered $500-\mathrm{ml}$ flasks containing the odor sample papers. Odorized air leaving the flasks passed through one of four stopcocks and back through a manifold where the four lines were recombined to form the stimulus air line. The clear-air line (also regulated by a stopcock) was connected beyond the second manifold to the stimulus air line. The stimulus-air line connected to one side of a " $U$ "-shaped tube. The other side of the " $U$ " tube was connected to a second clean-air line. This second clean-air line was used along with the other clean-air line only prior to the testing session to purge the " $U$ " tube. At the bend of the " $U$ " tube was a 1.0-mm-long glass pipette of $1.0 \mathrm{~mm}$ od. This pipette was inserted into the subject's naris. By manipulating a system of stopcocks, either clean air or any one of the four odor stimuli could be presented to the subjects. The stopcocks were manipulated in such a way as to insure that there was never an interruption of air flow or a change in air pressure to the subjects. The stimulus delivery system was constructed entirely of glass. Figure 1 is an illustration of this apparatus.

The stimulus collection apparatus consisted of a straight runway. The runway was $101 \mathrm{~cm}$ long and was divided into three sections: a 25-cm-long startbox, a 38-cm-long alleyway, and a 38-cm-long goalbox. The food cup, which was always baited, was located outside the end of the goalbox and was accessible through a 4-cm-diam hole in the end of the goalbox. Access to the goalbox was allowed (on reward trials) by raising a guillotine door. Food odor was allowed to pass into the goalbox on nonreward trials via $16 \quad 1.0-\mathrm{mm}$ holes drilled through the door in a circle corresponding to the access hole in the wall of the goalbox. Each of the sections of the runway was covered by semiopaque 
Plexiglas. The floor of the runway, which was $10 \mathrm{~cm}$ wide, was also covered by Plexiglas. Running from a slit in the base of the back wall of the startbox was a strip of adding-machine paper covering the length of the runway and exiting through a slit in the floor of the goalbox just prior to the guillotine door that blocked access to the food cup in the goalbox. Two microswitches, located beneath the Plexiglas floor recorded the subject's time from entering the goalbox to arrival at the door covering the access hole to the food cup. Times were measured to the nearest 5.0 msec by Standard Electric timers. The entire runway was painted with flat gray enamel.

\section{Procedure}

The section of paper covering the goalbox was collected after reward trials $(\mathbf{R})$ and nonreward trials $(N)$ in the following manner. The eight subjects were run in squad order in a RRNNRRNN or NNRRNNRR sequence such that every animal in the squad ran the first trial before any started the second trial. The sequences alternated over test days. On reward trials, the subjects had access to the food cup for $20 \mathrm{sec}$. On nonreward trials, the subjects were confined to the goalbox for $20 \mathrm{sec}$ with the food-access door closed. On reward trials, the food-access door was opened when the subjects closed the second microswitch stopping the elapsed time clock. The paper covering the entire runway was changed after each sequence of two similar trials (NN or RR). Goalbox paper sections from the second $\mathbf{R}$ couplet and the second $\mathbf{N}$ couplet were cut from the strip of runway paper and placed, using forceps, into separate $500-\mathrm{ml}$ flasks and sealed immediately. The runway subjects were assumed to be patterning reliably when at least six of the eight animals in the squad showed consistently longer times on the two nonreward trials than on the two reward trials.

The urine sample was collected at the same time that the runway samples were being collected. The urine was collected from a female rat housed in a metabolism cage equipped with a urine separation funnel. The urine was placed on a goalbox-length strip of paper and sealed in one of the flasks. A food sample was removed from the food cup and placed on a similar length of paper and placed in another flask.

Surgery. Surgical procedures included the insertion of a catheter in the external jugular vein and a tracheotomy to allow for artificial respiration. A detailed description of these procedures is presented in Mercer and Remley (1979). Prior to testing, an injection of gallamine triethiodide (Flaxedil; Davis and Geck Co.) was administered through the venous catheter $(1.0-1.6 \mathrm{cc} / \mathrm{kg})$. Paralysis was indicated by the slowing of respiration, at which time the subject was placed on the respirator. In order to eliminate pain and minimize discomfort to the animal, all areas of incisions and contact points were locally anesthetized with subcutaneous injections of $2.5 \%$ procaine HCL. Additional injections of the procaine HCL were given at 2-h intervals. Additional injections of Flaxidil were given as needed to insure the absence of movement by the subjects.

Recording. The microelectrode was lowered through a trephine hole in the skull until the electrical pattern on the oscilloscope indicated that the electrode was touching the surface of the olfactory bulb. Baseline coordinates were recorded at this point as a point of reference. The electrode was then lowered using a hydraulic microdrive until the electrode reached the mitral cell layer.

Testing of a cell began by recording the firing rate during a 3.0-min period of clean air presentation. The mean firing rate for the last $1.0 \mathrm{~min}$ of this $3.0-\mathrm{min}$ period was used as the clean air baseline value. Following the initial clean air presentation, one of the odor stimuli was presented. Each stimulus presentation lasted for $90 \mathrm{sec}$, with a clean-air presentation between stimulus presentations. Each clean-air period was $60 \mathrm{sec}$ in duration or longer if necessary for the cell to return to baseline firing rate. The sequence for stimulus presentation was random except that each cell was tested first with either nonreward paper or reward paper. After the last of the four odors was presented, clean air was reintroduced and a new cell was isolated. At the end of the recording session, a lesion was made by passing $.1 \mathrm{~mA}$ of dc current through the electrode for $8.0 \mathrm{sec}$. The last cell from which recordings were made was the site of the lesion. All other cells were located in reference to these sites.

For histological examination, the animal was overdosed with chloral hydrate and perfused intracardially with saline, followed by $10 \%$ neutral buffered Formalin. The brain was removed, fixed in Formalin, embedded in celloidin, and sectioned at $30 \mu$ throughout the extent of the trephined area. The tissue was stained with thionine and mounted for microscopic examination.

\section{RESULTS}

The significance criterion established for the stimulus collection procedure was met on all days when the goalbox paper was used as the stimulus for the recording subjects. The data of the speed scores for the odor-donor subjects are illustrated in Figure 2. Analysis of variance of these data shows a statistically significant effect of reward vs. nonreward trials $[\mathrm{F}(1,385)=270.98, \mathrm{p}<.01]$.

A total of 186 cells were isolated and recordings made of their firing rates. Of this population, 178 cells had at least one stimulus presented for the three 90-sec periods. The data recorded from each cell were divided into sample periods in the following manner: The final $1 \mathrm{~min}$ of the initial 3-min clean-air baseline recording was divided into two bins of $30 \mathrm{sec}$. The mean firing rates for these bins were then averaged to obtain a mean baseline firing rate. The mean firing rate for the three 30-sec bins of the first odor presentation was compared with the clean-air baseline

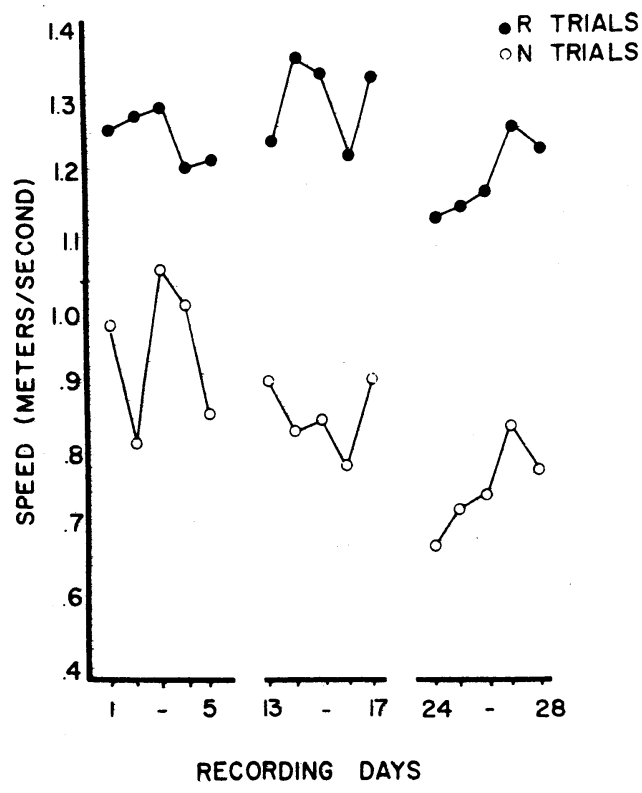

Figure 2. Mean speed scores of the odor-donor subjects for reward and nonreward trials on representative recording days. 
firing rate. The subsequent clean-air presentation was used as the standard of comparison for the next odor presentation. A difference in percentage equal to or greater than $20 \%$ of the baseline firing rate was designated as a significant change in activity.

The responses of a cell over the three presentations of an odor stimulus generally divided into three categories: consistent responding $(* * *)$, in which each of the three 90 -sec presentations caused a significant change in firing rate; partial responding $\left(--^{*},-{ }^{* *}\right.$, ${ }^{*}--,^{* *}-,^{*}-^{*}$, or $\left.-{ }^{*}-\right)$, in which only some of the stimulus presentations caused a change of $20 \%$ or greater; and no response (- - -), in which none of the stimulus presentations caused a significant change.

Over $50 \%$ of the cells tested did not show consistent responses; that is, the cell's responses on the three 90 -sec stimulus presentations were not uniform. These cells were divided into three categories: sensitizing cells, which showed no significant change during the first or first and second presentations of a stimulus and a subsequent stimulus bound change $\left(-* *,--^{*}\right)$, and habituating cells, which showed a stimulus bound change on the first or first and second stimulus presentations but no change on subsequent presentations $\left({ }^{*}--,{ }^{* *}-\right)$. The third category of cells could not be classified as either sensitizing or habituating $\left(-^{*}-,^{*}-{ }^{*}\right)$. These unclassified cells make up the majority of the partial responding category, as might be expected in a system that adapts as rapidly as does the olfactory system.

A specific response was defined as a change in direction of firing rate (excitation or inhibition) of a cell in response to one stimulus that was different from the response shown to the other three stimuli.

Of the 164 cells tested with the nonreward paper, 80 cells had a consistent response, 69 cells had a partial response, and 15 cells showed no response. Twentyfive cells (consistent and partial responses) showed a specific response to the nonreward paper. Figure 3 illustrates the data derived from a cell having a different response to the nonreward paper than to any of the other stimuli.

Of the 161 cells tested with the reward paper, 78 cells had a consistent response, 65 cells had a partial response, and 18 cells had no response. There were 26 cells which had a specific response to the reward paper. Figure 4 illustrates the data of one of these cells.

Of the 149 cells tested with both the reward and nonreward papers, 59 responded differently to these two stimuli. That is, the cell responded with excitation to one stimulus and with inhibition to the other. Some of these cells, however, also responded to either the urine paper and/or the food paper. Of the 121 cells tested with all stimuli, 25 showed a specific response to the odor from the nonreward paper,

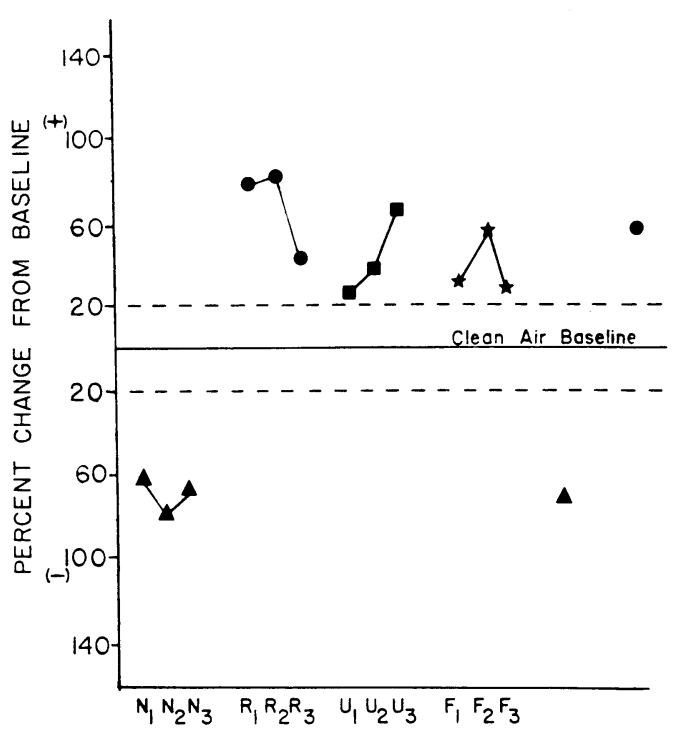

Figure 3. A mitral cell that had a specific response to the odor of nonreward. Each point represents the mean of one 90 -sec period change from baseline firing rate. The single points represent a retest of the $N$ paper and $R$ paper after all the stimuli had been tested in the usual manner. The odor of stimulus presentation was reward, urine, nonreward, food.

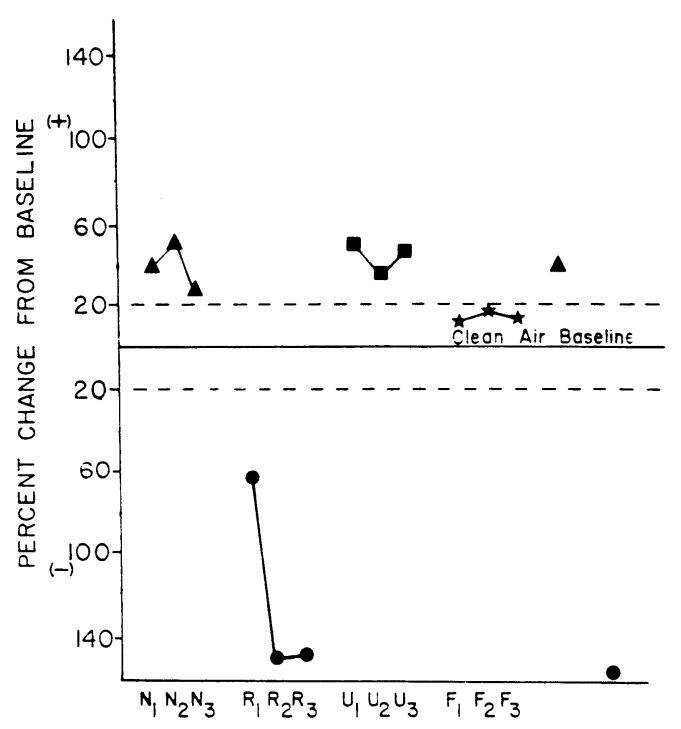

Figure 4. A mitral cell that had a specific response to the odor of reward. Each point represents the mean of one 90 -sec-period change from baseline firing rate. The single points represent a retest of the $\mathbf{N}$ paper and $\mathbf{R}$ paper after all the stimuli had been tested in the usual manner. The odor of stimulus presentation was reward, food, nonreward, urine.

26 cells showed a specific response to the odor from the reward paper, 31 cells showed a specific response to the food paper, and 11 cells showed a specific response to the urine paper.

A summary of the data is presented in Table 1. 
Table 1

Responses of Single Mitral Cells From Rat Olfactory Bulb to Odor Stimuli Generated in a Straight Alleyway

\begin{tabular}{|c|c|c|c|c|c|c|c|c|c|c|}
\hline & \multirow{2}{*}{$\begin{array}{l}\text { Number } \\
\text { Tested }\end{array}$} & \multicolumn{2}{|c|}{ No Response } & \multicolumn{4}{|c|}{ Consistent Response } & \multicolumn{2}{|c|}{ Partial Response } & \multirow{2}{*}{$\begin{array}{c}\text { Specific } \\
\text { Response }\end{array}$} \\
\hline & & Total & Percent & Total & Percent & + & - & Total & Percent & \\
\hline Nonreward-Paper & 164 & 15 & 9 & 80 & 49 & 39 & 41 & 69 & 42 & 25 \\
\hline Reward-Paper & 161 & 18 & 11 & 78 & 48 & 33 & 45 & 65 & 40 & 26 \\
\hline Urine-Paper & 143 & 17 & 12 & 70 & 49 & 26 & 44 & 56 & 39 & 22 \\
\hline F-Paper & 138 & 19 & 11 & 51 & 38 & 17 & 34 & 64 & 48 & 31 \\
\hline
\end{tabular}

Note $-+=$ excitatory response; $-=$ inhibitory response.

\section{DISCUSSION}

A problem in the behavioral research which had not been resolved is whether there is one or two odors, a "nonreward" and a "reward" odor, or only one odor, with the other goalbox condition being merely the absence of that odor. The present data are consistent with the interpretation that there are different odors on reward and nonreward trials and that these odors are present on the paper covering the floor of the goalbox. The data also show that the odors are volatile and remain active for at least $8 \mathrm{~h}$ in a container with air being passed over the paper.

The mitral cell responses to the nonreward paper samples produced some rather strong evidence that the odors of these paper samples were different from the other stimuli presented. The 25 cells with specific responses to the nonreward paper sample clearly support this differentiation of stimuli. The specific responses were divided into three categories: (1) cells that showed an excitatory or inhibitory response to the nonreward paper accompanied by no change in responding to the other stimuli, (2) cells that showed no change to the nonreward paper with an excitatory or inhibitory response to the other three stimuli, and (3) cells that showed a response to nonreward paper that was in the direction (excitation or inhibition) opposite to that of the response of the cell to the other three stimuli. The first two categories of specific responses could possibly be explained by a concentration difference of identical odors. However, in the third category, it is not possible from what is known about the functioning of the mitral cells to find responses of a single cell in opposite directions to the same odor regardless of concentration differences. MacLeod (1971) states:

The bulbar units usually display ... on chemical stimulation three possible types of responses: excitation, inhibition, or no response. When the stimulus is changed the response of a given unit may or may not change. The same unit always gives the same response to the same substance and does not vary with stimulation intensity .... Only frequency of firing was significantly related to the stimulation; pattern of firing on the opposite, appeared rigidly characteristic of units and independent of stimulation (p. 198).

Taken together, these data are consistent with the conclusion drawn from the behavioral data, that there is a specific odor associated with the condition of nonreward, and that this odor is different from the odors associated with reward, food, or urine.

The arguments presented above for the assertion that there is an odor associated with nonreward are also applicable to the assertion that there is also an odor associated with reward. This conclusion is in agreement with those reported by Cattarelli et al. (1975) and Cattarelli et al. (1977). They reported

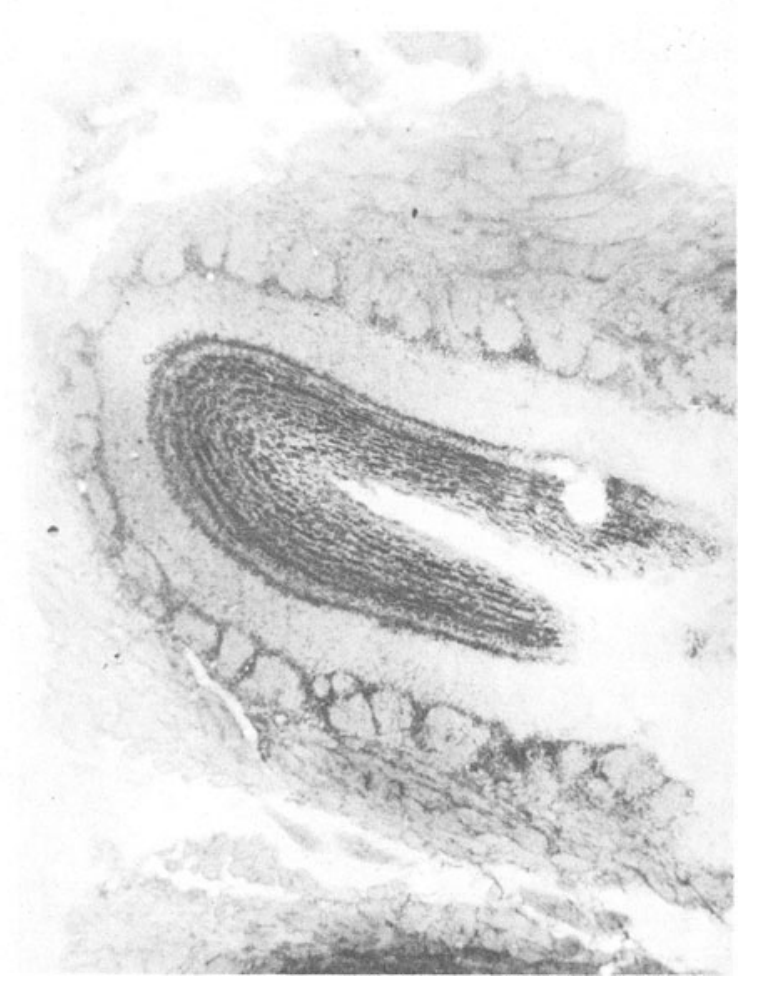

Figure 5. Photomicrograph of rat olfactory bulb. Lesion indicates location of microelectrode. 
that there were different percentages of cells showing excitation or inhibition to "nonreward" and "reward" odors. In the data reported here, 26 cells had a specific response to the odor from the reward paper sample.

The conclusion inferred from the electrophysiological data that it is not "food" odor that is specific to the reward condition is supported by the fact that in the alleyway used for stimulus collection there was "food" odor on both reward and nonreward trials. The behavior of the donor animals clearly demonstrates that the animals were able to discriminate the reward from the nonreward trials even though "food" odor was present on both types of trials. The same logic is also applicable to the conclusion that the odor of urine is not the odor apparently used by the donor subjects, for urine was also present on both the reward and nonreward trials.

It must be stressed that the present research does not address the issue of what these odors from the goalbox consist of, or of what the receptor mechanisms might be. The data only demonstrate that specific reward and nonreward odors are detected at the level of the mitral cells in the olfactory bulb.

There is one finding that is tempting to speculate about, and that is the observation of similar responses to some of the odors if examined as pairs. Doving (1966) has reported that the closer together substances are chemically, the more similar their olfactory stimulative properties. Of the pairwise comparisons for similar responding, the "nonreward" and "reward" odors show the largest number of similarly responding cells. These two odors may be much more similar than are some pairs of odors such as "nonreward" and "food." Examined from a behavioral approach, this might explain the difficulty that some animals have in making a discrimination in the alleyway unless given many trials or a very concentrated collection of odors.

The most frequently used hypothesis that has attempted to explain the behavioral results of this subjectgenerated odor phenomenon has been the "frustration" odor hypothesis (Ludvigson, Note 2). This hypothesis proposes that upon reaching an empty goalbox where food has been encountered in the immediate past, the subject is frustrated and emits a particular odor associated with this state. Behavioral evidence has clearly shown that an odor is emitted and can be used as a cue by conspecifics to predict the upcoming goal event. This hypothesis has been extensively tested, and most of the data tend to support the idea of a "nonreward"' odor linked to frustration.

A second possible interpretation of these data might be called a "food vs. no food" hypothesis. This hypothesis assumes that the rat emits an ethologically significant odor (pheromone) when en- countering food, thereby signaling the location of food to conspecifics. The hypothesis also assumes that when encountering food stimuli (food odor, for example), but no food, the rat emits a pheromone signaling "food is no longer at this location" to conspecifics.

The data generated by the present research can fit with either hypothesis. The differential direction of responding of cells to the odors from reward paper and nonreward paper indicates specific odor components on the two papers. The odor on the nonreward paper could very well be the result of frustration. The odor on the reward paper could be ignored by the subject, particularly if the presence of a stronger olfactory cue on the nonreward paper is enough to predictably establish the presence or absence of food. Responses of cells at the mitral cell level in the olfactory bulb make no statement about the final behavioral output of the animal other than that the subject is able to detect an odor.

On the other hand, the "food vs. no food" hypothesis seems to be more in agreement with our understanding of pheromonal communication in social species. It would seem that the ability to signal "no food here" in a location where food was previously found would have important adaptive advantage for an animal that is often a prey.

This research has demonstrated that it is possible to collect "reward" and "nonreward" odors on paper covering the floor of a goalbox in a straight alleyway. It has shown that these odors are different, not only from each other, but also from the odors of urine and food. The behavioral data shows that conspecifics can utilize these odors to predict the subsequent goal event. Further research will be required to determine whether there is, in fact, an odor of "frustration," or whether these odors are natural pheromones used to signal the presence or absence of food to conspecifics.

\section{REFERENCE NOTES}

1. Prytula, R. E. The role of odor and memory in single and double alternation schedules. Paper presented at the meeting of the Southwestern Psychological Association, San Antonio, 1979. 2. Ludvigson, H. W. "Frustration odor" in rats. Paper presented at the XXVII International Congress of Physiological Science, Paris, July 1977.

\section{REFERENCES}

Cattarell, M., Vernet-Maury, E. T., \& Chanel, J. Influences de differentes odeurs biologiques sur le comportement émotif du rat place dans un "escape vide d'informations." Comptes Rendus de l'Académie des Sciences Paris, 1974, 2653-2656.

Cattarelli, M., Vernet-Maury, E. T., \& Chanel, J. Modulation de l'activité du bulbe olfactif en fonction signification des odeurs chez le rat. Physiology \& Behavior, 1977, 19, 381-387. 
Catarelli, M., Vernet-Maury, E., Chanel, J., Macleod, P., \& Breandon, A. Olfactory bulb and integration of some odorous signals in the rat-Behavioural and electrophysiological study. In D. A. Denton \& J. P. Coghlan (Eds.), Olfaction and taste (Vol. 5). New York: Academic Press, 1975.

Collerain, I., \& Ludvigson, H. W. Aversion of conspecific odor of frustrative nonreward in rats. Psychonomic Science, 1972, 27, 54-56.

Colle rain, I., \& Ludvigson, H. W. Hurdle-jump responding in the rat as a function of conspecific odor of reward and nonreward. Animal Learning \& Behavior, 1977, 5, 177-183.

Davis, S. F., Prytula, R. E., Noble, M. J., \& Mollenhour, M. T. Motivational specificity of the signal value of odor cues. Animal Learning \& Behavior, 1976, 4, 407-410.

Doving, K. B. An electrophysiological study of odour similarities of homologous substances. Journal of Physiology (London), 1966, 186, 97-109.

EsLINGER, P. J. Attempts to isolate with gas liquid chromatography chemical differences between reward and frustrative nonreward odor emissions in the rat. Unpublished doctoral dissertation, Texas Christian University, 1980.

Eslinger, P. J., \& Ludvigson, H. W. Commonality among rats in production of reward and nonreward odors. Bulletin of the Psychonomic Society, 1980, 16, 191-193.

Howard, C. S., \& McHose, J. H. The effects of sodium amo- barbital of odor-based responding in rats. Bulletin of the Psychonomic Society, 1974, 3, 185-186.

Ludvigson, H. W., \& Sytsma, D. The sweet smell of success: Apparent double alternation in the rat. Psychonomic Science, 1967, 9, 283-284.

MACLEOD, P. Structure and function of higher olfactory centers. In L. M. Beidler (Ed.), Handbook of sensory physiology (Vol. 4). New York: Springer-Verlag, 1971.

Mellgren, R. L., Fouts, R. S., \& Martin, J. W. Approach and escape to conspecific odors of reward and nonreward in rats. Animal Learning \& Behavior, 1973, 1, 129-132.

Mercer, L. F., JR., \& RemLey, N. R. Mapping of sensoryresponsive cells in the septal area of the rat. Brain Research Bulletin, 1979, 4, 483-490.

Pratt, L. K., \& Ludvigson, H. W. The role of odor in latent extinction. Psychonomic Science, 1970, 20, 189-190.

Seago, J. D., Ludvigson, H. W., \& Remley, N. R. Effects of anosmia on apparent double alternation in the rat. Journal of Comparative and Physiological Psychology, 1970, 71, 435-442.

Wasserman, E. A., \& Jensen, D. D. Olfactory stimuli and the “pseudoextinction" effect. Science, 1969, 166, 1307-1309.

(Received for publication November 24, 1980; revision accepted May 18, 1981.) 